Harris, K. \& Bradley, D. E. (1958). J. gen. Microbiol. 18, 71-83

\title{
Some Unusual Chrysophyceae Studied in the Electron Microscope
}

\author{
BY KATHERINE HARRIS \\ Department of Botany, University of Reading \\ AND D. E. BRADLEY \\ Research Laboratory, Associated Electrical Industries Ltd., \\ Aldermaston, Berkshire
}

\begin{abstract}
SUMMARY: Three members of the Chrysophyceae are described, the general morphology being studied with the light microscope, but the details of the scale and bristle structure with the electron microscope. Mallomonas ouradion sp.nov. is at present unique in having several movable bristles on each scale. Chrysosphaerella brevispina Korshikov is shown to include $C$. rodhei Skuja. The peculiar bristle base is elucidated. This is the first record for the genus in Britain. Synura sphagnicola is shown to differ in several respects from other species of Synura. In all three genera, the chromatophore, which has been described as double, is shown to be single but strongly lobed. Replicas of the intact armour of S. echinulata are shown.
\end{abstract}

The classification of the species of Mallomonas, Chrysosphaerella and Synura has used the minute silica scales and bristles with which these organisms are covered, in addition to the general morphology of the cell itself. The sculpturing of the scales is, for the most part, beyond the resolution of the light microscope, so that classification based on these features was necessarily somewhat vague. The high resolution of the electron microscope has permitted the smallest structural details of the scales to be seen, and the use of replica techniques has enabled arrays of scales on complete organisms to be studied and also the front and back of the scales to be distinguished (Harris \& Bradley, 1957). As a result, differentiation between species has become much easier, making possible a fuller and clearer classification and the identification of many new species.

\section{METHODS}

\section{Collection of organisms}

Samples of pond water were collected and the organisms concentrated by centrifuging at about $2000 \mathrm{rev}$./min. A drop of concentrate was then examined in the light microscope and the living organisms identified as nearly as possible and drawn. Cytological observations were made mainly on living material, though, when necessary, they were confirmed with fixed material. The methods of fixation used were either one half-minute exposure to osmic acid vapour or the addition of a drop of the algal concentrate to a minute drop of osmic acid solution or strong formalin previously placed on a slide. The latter method was used where there was a covering of mucilage on the colonies, as the fixative seemed to penetrate the mucilage better when used in this way, 
tending to prevent the colonies from breaking up. No method of fixation was wholly satisfactory. For examination of scales and bristles, preparations were made by allowing a drop of the concentrate to dry on the slide. This could be examined with the light microscope either dry or mounted in resin of high refractive index, or used after further treatment for examination in the electron microscope.

\section{Electron microscopy}

The specimens were examined in the electron microscope, both directly and by means of carbon replicas (Bradley, 1954a). Preparative techniques have been described in detail elsewhere (Harris \& Bradley, 1957), so that only a brief outline need be given here. In the case of direct examination, the slide on which the organisms had been mounted was coated with a layer of carbon to act as a support film (Bradley, 1954b). This deposit was then backed with plastic, and the combined film, with the organisms embedded in it, was floated on to water and cut into small pieces. These were mounted on specimen support grids, and the plastic backing washed away with a suitable solvent. The organisms remained within the carbon film and were ready for examination in the electron microscope.

Where replicas were required, a plastic-backed carbon film containing the organisms was prepared as above, and then floated on $50 \%(w / v)$ hydrofluoric acid for $15 \mathrm{~min}$. to dissolve the silica scales and bristles. Organic matter was removed by means of a solution of potassium permanganate in sulphuric acid. The plastic backing was washed away as before, and the carbon 'shell' which constituted the final replica shadowed and examined in the electron microscope.

These two methods of examination were used because it was found that the morphology of the scales is most clearly visualized by combining the information provided by replicas and by direct examination. The reason for this is that the mechanism of contrast formation by the scales themselves is completely different from that of replicas. In the cases of the scale itself, internal structure is shown and punctate markings more clearly seen; with a replica, a marked three-dimensional effect is produced, inner and outer surfaces of the scales may be differentiated, and a more easily interpreted picture is obtained.

Electron micrographs of replicas are printed as negatives so that it appears as if the scales are illuminated obliquely by white light.

\section{RESULTS}

MALLOMONAS OURADION sp.nov.

This is a new species and is illustrated in Figs. 1-5, PI. 1, figs. 1-7 and Pl. 2, fig. 8.

\section{Diagnosis}

Cellula ovoides, semper ferme $20-25 \times 10-15 \mu$., setis multis gracilibus contacta. Chromatophorum solum prope in lobos duo divisum, colore subpallido. Flagellum longius quam corpus, squama ovalis, semper ferme 5-7 $\times 3-4 \mu$., scutum et margo praesens sed cupola absens; scutum externe papillis parvis 
tectum; margo latus politus; squama tota interne levis, cavulo parvo in parte remota a margine verisimiliter poris minutis indistinctis plerumque sparsa. Squama setas tres inter quinque ferens, basis setae lata, subter inflecta vel uncinata, truncus setae rectus, 4-12 $\mu$. longe, profunde, sulcatus; apex setae in cuspides duo equales furcatus.

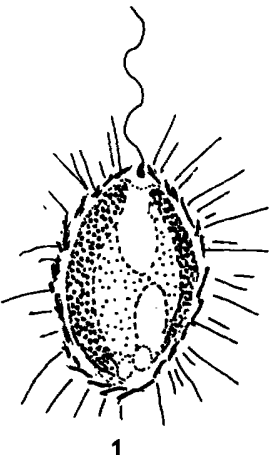

1

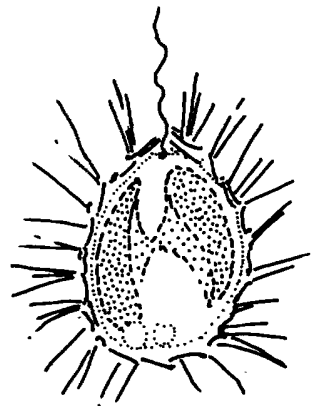

2

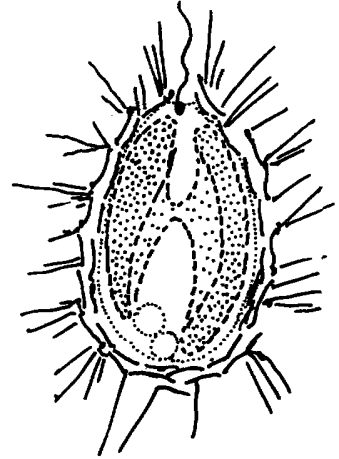

3
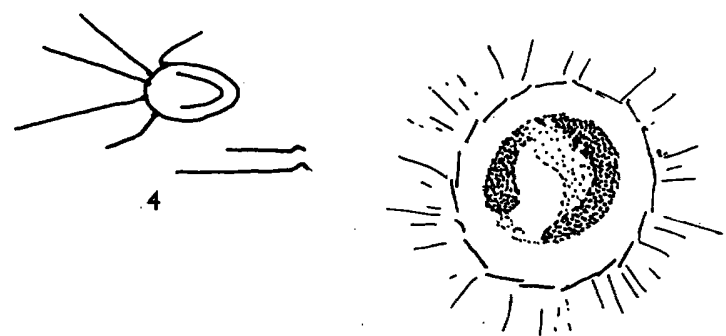

5

Figs. 1-5. Mallomonas ouradion. Fig. 1. Individual $; \times 1000$. Fig. 2 . Individual replacing two anterior scales; $\times 1000$. Fig. 3. Individual replacing all scales; $\times 1000$. Fig. 4 . Scale and two bristles; $\times 2000$. Fig. 5. Individual in spherical condition.

Cell ovoid, typically 20-25 × 10-15 $\mu$., covered all over with numerous delicate bristles. Chromatophore single, deeply divided into two lobes, rather pale in colour. Flagellum over body length. Scale oval, typically 5-7 $\times 3-4 \mu$. having shield and flange but no dome; shield covered on outer side with small papillae each pierced by a small hole; flange broad, smooth; underside of whole scale smooth but with slight hollow at end opposite flange; most of underside probably covered with minute indistinct pores. Bristles 3 to 5 per scale; base of bristle broad, sharply bent or hooked, shaft straight, 4-12 $\mu$. long, smooth, deeply grooved, enlarged and forked into two equal parts at the tip.

The name ouradion, a fish tail, refers to the shape of the bristle tip.

For terminology see Harris \& Bradley, 1957.

Occurrence. Common near Reading, May to October in peaty pools, usually with Sphagnum, occurring with Synura sphagnicola Korsch. It is easily overlooked because of its small size. 


\section{Discussion of Mallomonas ouradion}

The chromatophore of Mallomonas ouradion is similar to that found in many species of Mallomonas (Harris, 1953). The two rather broad lobes, situated in the peripheral protoplasm and curving round the cell, look at first sight like two separate chromatophores. The connexion between the lobes is delicate and pale, while the lobes themselves are a distinct brownish green colour (Figs. 1-3 and 14). The nucleus is enclosed by the lobes at the anterior end of the cell and is distinct. A leucosin body is usually present between the lobes in the rear part of the cell and, as in all species of Mallomonas, varies in size at different times.

Mallomonas ouradion is at present unique in that the scales bear from three to five bristles, and not a single bristle as in all other known species of the genus (Fig. 4 and Pl. 1, fig. 3). The bristles have a base which is unusual in being expanded like a spade. It is sharply bent and fits under the shield into a slight hollow (Pl. 1, figs. 2, 5 and 6). The bristles are expanded at their free ends into the shape of a fish tail, a shape characteristic of this species alone.

The presence of several bristles on a scale raises the question whether this species should be considered the type of a new genus. We refrained from suggesting this classification because Mallomonas ouradion seems to be a typical Mallomonas in its other characteristics.

One scale shown in Pl. 2, fig. 8, is unlike the others in being without papillae. This scale, partly overlapped by two others and seen near the right of the figure, must be showing its outer surface since the characteristic marginal flange is present. No papillae can be seen except three or four possible vestiges on the lower margin. We regard this as an immature scale replacing one that has been shed. We know already that scales are shed and replaced in Mallomonas individuals (Harris, 1953). Fig. 2 shows one individual in which the anterior scales appear to have been replaced before the old ones have been shed, and Fig. 3 shows an unusual individual in which two complete layers are present. If our interpretation of this smooth scale is correct, then it has a special interest in suggesting that the scales are first produced as delicate plates of full size and that the external sculpture is added afterwards.

No cyst has been seen, but Mallomonas ouradion can pass into a peculiar state in which the organism is spherical and the protoplasm is shrunk away from the scale armour, forming an interior sphere (Fig. 5). This condition was not a transient one; large numbers of these spheres were found, and they persisted in the bottle for several days without change. Gradually they disappeared, presumably through death.

\section{History of the genus Chrysosphaerella Lauterborne}

Chrysosphaerella has been recorded from a few lakes in various parts of Europe and the United States. The type is C. longispina Lauterborn (1896, 1899). It was recorded with figures by Smith (1933), redescribed by Korshikov (1941-42) and recorded with figures by Skuja (1948). The record by Conrad (1941) appears to have been C. brevispina Korsch. not C. longispina 
Lauterborne. Two other species besides $C$. longispina have been recorded, but our observations indicate that they should be united. The earlier is C. brevispina Korshikov (1941-42), and the later C. rodhei Skuja (1948). The latter has also been described by Fott \& Ludvik (1956) from scales and bristles found in peat and examined in the electron microscope, but they did not see any living material.

\section{Chrysosphaerella brevispina Korshikov, emend.}

This organism is illustrated in Figs. 6-9 and Pl. 2, figs. 9-13.

Light microscopy. Chrysosphaerella brevispina is a colonial organism with ovoid cells. These possess delicate scales and a few long bristles. The colony is usually coated with mucilage which takes up methylene blue and resists penetration by indian ink. A number of loose scales appear to be embedded in the mucilage. In a broken colony, we were able to observe that the centre is hollow, the cells not being joined by strands of protoplasm (Fig. 6).

Isolated living cells have a membrane which seems to be covered all over with exceedingly delicate scales, although their arrangement cannot be seen (Fig. 7). It is impossible in a living colony to see whether the scales surround each cell or are confined to the outer free surface of each cell. In both isolated cells and colonies, bristles may be seen, apparently arising from small plates situated just outside the cell membrane. We did not succeed in obtaining any successfully fixed cells in which the scales retained their original position. We think that the difficulty may have been caused by mucilage slowing down the penetration of fixative. The cells always disintegrated as they died. Thus the only indications as to the arrangement of the scales are such as can be seen on the living cell. There are up to seven bristles attached to each cell. These may be most easily counted in dried material, though their arrangement is disorganized. Fig. 6 shows a group of scales and bristle bases as they appear when they have been mounted in resin. The bristle tips look simple at this magnification.

The chromatophore of Chrysosphaerella brevispina differs, in our opinion, from any description hitherto given. Normally the chromatophore is single but deeply divided into two lobes. The connexion between these lobes is narrow and exceedingly delicate so that, in many positions, the lobes look like two separate chromatophores (Fig. 7). A refractive spot may be seen in the extreme anterior tip of one or both lobes. At certain times in the life cycle of the organism, two small separate chromatophores may be seen in a cell. Each of these is divided into two lobes by a slight constriction. Cells with these chromatophores, and others with normal chromatophores, were found side by side in the same colony (Fig. 6), both in early March, when the species was first found, and in April, at the time of cyst formation. We believe that these small chromatophores are the product of chromatophore division either in preparation for cell division, or for the formation of binucleate cysts such as are to be seen in many of the Chrysophyceae, particularly in C. longispina Skuja (1948). Two cysts were found $11 \mu$. in diameter (Fig. 8).

Electron microscopy. The examination of Chrysosphaerella brevispina in the 


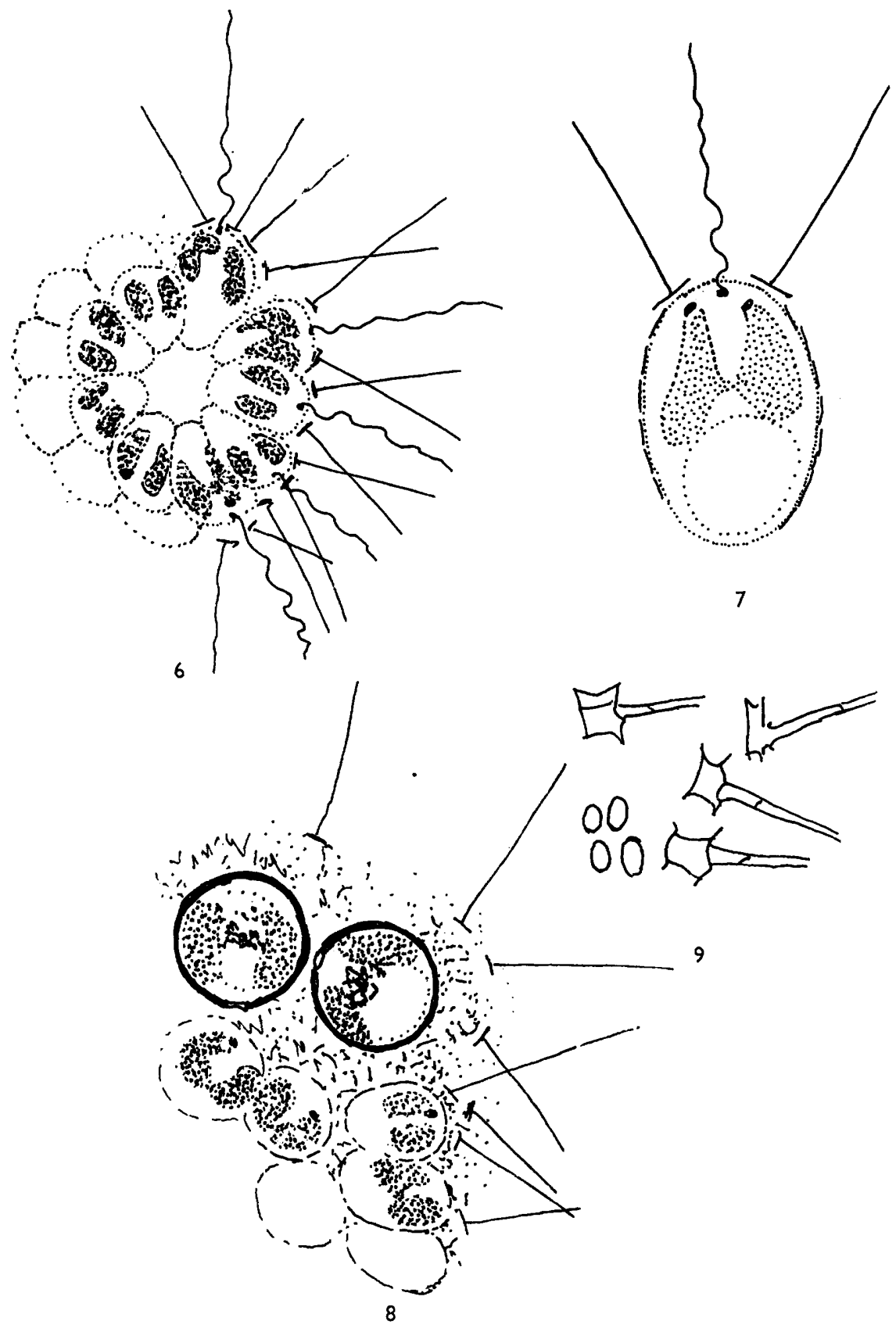

Figs. 6-9. Chrysosphaerella brevispina Korsch. Fig. 6. Broken colony; $\times 1000$. Fig. 7. Individual cell; $\times 2000$. Fig. 8. Part of colony including two cysts; $\times 1000$. Fig. 9 . Scales and bristles; $\times 2000$. 
electron microscope elucidates what has been seen in the light microscope and adds much to our knowledge. The replicas show that the inner and outer surfaces of the scales are different (Pl. 2, figs. 10, 11). The outer surface shows a conspicuous row of pits just inside the margin, but the inner surface shows only a wavy fold along the inner edge of these pits. The direct electron micrograph shows both features superimposed; in some scales the pits, but in some the edge of the fold, are more clearly marked (Pl. 2, fig. 11).

The bristle is hollow, with two prongs at its tip, one usually longer than the other (Pl. 2, fig. 13). At this high magnification something of the structure of the bristle wall can be seen; its outer layers appear to be flaking off. The base, from which the bristle arises, could be described as bobbin-like, or as two concave disks joined by a hollow tube on which the bristle is placed excentrically. The hollow tube of the base is continuous with the hollow bristle (Pl. 2, figs. 9, 12). The rim of the outer disk bends back to a greater or lesser extent. This turned-back rim catches the light and is the only part of the bristle to show when the living cell is examined in the light microscope. It is seen as the single bright refractive plate already described.

Occurrence. We have found Chrysosphaerella brevispina in four ponds near Reading, all on acid soils but not associated with Sphagnum. It was found in March and April, in the cold spring of 1956, sometimes under ice. It encysted in April. It was not found at all in the mild spring of 1957.

Discussion. Skuja differentiated Chrysosphaerella rodhei Skuja from C. brevispina Korshikov on the character of the chromatophore and of the bristle base. The chromatophore described and figured by him appears to us to be the normal bilobed chromatophore which we found in C. brevispina. The fact that he speaks of two chromatophores would be explained if, as we think likely, he had missed the small and delicate connexion between the two lobes. The chromatophores described by Korshikov as 'biscuit-shaped' resemble very closely the chromatophores we found present in some cells at certain times, and which we believed were the result of division. If we are right, the differences between the chromatophores described by these two authors are not specific but developmental.

Although Skuja states that the bristle base of Chrysosphaerella rodhei differs from that of $C$. brevispina his figures do not show any difference beyond the normal variation we found within the species we have examined.

The two cysts we found are smaller than those described by Skuja being $11 \mu$. in diameter instead of his 13-15 $\mu$. We do not think that this difference is significant. The range of variation in cyst size in the Chrysophyceae may be considerable within a single species.

In our opinion the species Chrysosphaerella brevispina Korshikov and $C$. rodhei Skuja are the same, and the name $C$. brevispina has priority.

The scales and bristles examined in the electron microscope by Fott \& Ludvik (1956) agree very closely with ours. There are, however, certain differences which should be mentioned. The outer part of the bobbin in their photographs is cup-shaped, and lacks the turned-back rim which appears in ours. The extent of this turned-back rim varies considerably in our electron 
micrographs though in the seven we have studied, none was precisely like Fott's figure. Fott also describes the bobbin as being screw-like. We think that this appearance in his figures is due to two foreign bodies touching the bobbin and distorting its outline. We believe that the species he described is Chrysosphaerella brevispina.

The species described by Conrad (1941) as Chrysosphaerella longispina appears to be C. brevispina. His photographs of the scales and bristles, and also his measurements, agree with ours and not with $C$. longispina Lauterborn. His specimens were found in spring, like C. brevispina while, so far, C. longispina has only been found in autumn.

\section{Description of the chromatophores of the genus Synura Ehrenbg.}

Synura is usually described as having two chromatophores but we have found the chromatophores to be single and deeply divided into two lobes in all the species which we have examined. The connexion between the lobes is so narrow and delicate that, unless the cell is favourably placed, it is invisible (Figs. 14-17).

\section{Synura sphagnicola Korshikov (synonym: Skadorsskiella sphagnicola)}

This organism is illustrated in Figs. 10-13, 16, and 17; Pl. 3, figs. 14-22 ; Pl. 4, figs. 23, 24).

Light microscopy. The light microscopy of Synura sphagnicola has been fully described by Korshikov, and only in a few points do we wish to add to or modify his description. It is a species which differs in a number of ways from all other well-known species, and this is an aspect which we want to emphasize.

(1) It is the only known species to have red droplets. These red droplets, whose nature is not known, are situated at the anterior end of the cell. They are not part of the chromatophore and cannot be called stigmas. They may be few or many, sometimes so numerous as to coalesce and form a red patch. It is possible that they may at times be absent. They disappear suddenly, almost explosively, as the organism dies. After fixing in osmic acid, they persist for a short time, then gradually fade and disappear. They are also present in the cyst, where they appear as red disks just inside or outside the chromatophore lobes, and in this position they are inconspicuous (Figs. 10, 11 and 13).

(2) The two flagella are notably different in length, one being one-half to two-thirds the length of the other, whereas, in most of the well-known species of Synura, the flagella are nearly but not quite equal (Petersen, 1918; Korshikov, 1941-42; Manton, 1955).

(3) The cells forming the colony lack the protoplasmic stalks characteristic of other known species. The cells are in contact laterally but not joined centrally in any way. This may be seen when a colony is broken, and also in a colony with four cysts (Fig. 13).

(4) The chromatophore is composed of two lobes which lie side by side in the middle of the cell, joined by a narrow strip placed at right angles to them (Figs. 16, 17). In all other known species of Synura, the chromatophore is placed near the peripheral cytoplasm and its lobes partially envelop the cell 
contents (Fig. 15). In the cyst of $S$. sphagnicola, as in all other species we have seen, the chromatophore lobes lie one each side of the pore in the outer protoplasm. The connexion between the lobes is rarely visible in the cyst (Fig. 13). Figs. 10 and 11 show the chromatophore in various positions and closely correspond to Korshikov's figures (reprinted Huber-Pestalozzi, 1941,

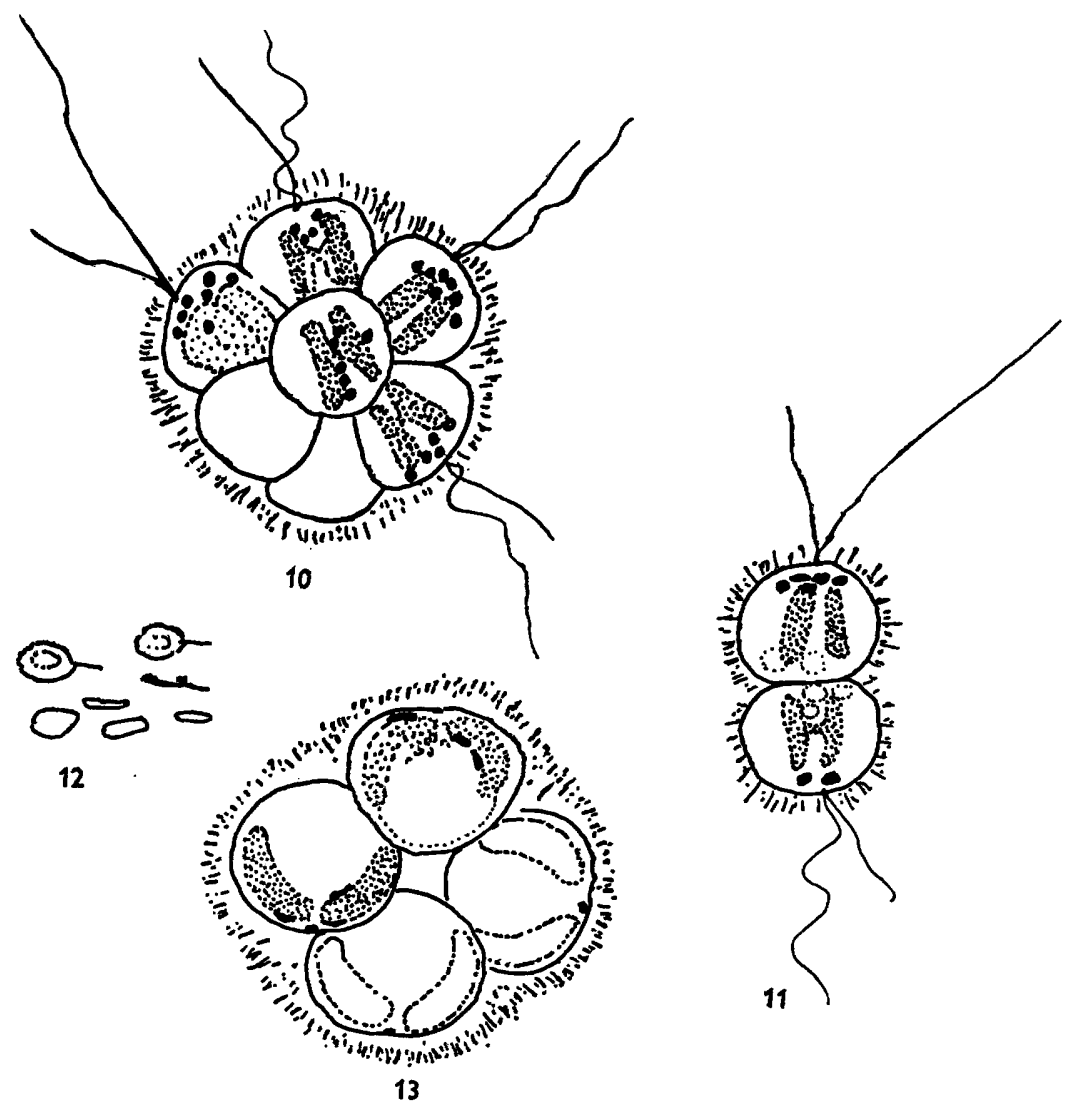

Figs. 10-13. Synura sphagnicola. Fig. 10. Small colony; $\times 1000$. Fig. 11 . Colony of two cells; $\times 1000$. Fig. 12. Group of scales, one seen edgewise; $\times 2000$. Fig. 13. Colony of four cysts; $\times 1000$.

p. 138) but Korshikov has not seen the inconspicuous connexion between the chromatophore lobes and has described the organism as having two chromatophores.

(5) In our experience, the colonies are surrounded by mucilage, which may vary in extent from a thin covering to a broad sheath in which refractive particles and scales are embedded. This zone takes up methylene blue and resists penetration by indian ink.

(6) The scales do not form a close armour as in most species of Synura, but appear to be set on end and point outwards.

(7) We found four cysts (Fig. 13), all of which are broader than long and 
flattened round the pore. They differ thus from the cyst shown by Korshikov, which is spherical. All other species of Synura which we know have spherical cysts.

Electron microscopy. The scales of Synura sphagnicola when examined in the electron microscope show a large variety of shapes. The majority are oval, each with a fairly long spine; some are narrow with a shorter spine or none, while others are spathulate with curled edges. Intermediates are found between all these types, and they correspond to the variants found in other species (Manton 1955; Petersen \& Hansen, 1956; Fott \& Ludvik, 1957; Pl. 3, figs. 14-20, 22). The basis of all the broader scales is a perforated plate

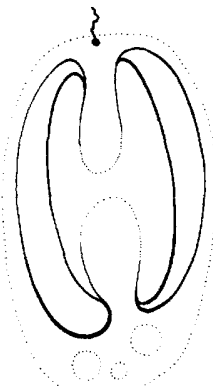

14

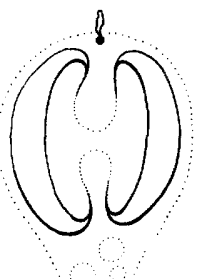

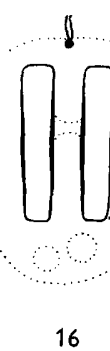

16

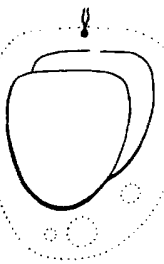

17

Figs. 14-17. Diagrams of chromatophores. Fig. 14. Mallomonas ouradion.

Fig. 15. Synura echinulata. Figs. 16, 17. S. sphagnicola.

flat on the inner surface, but with a thickened margin on the outer side. The hollow spine, which arises just inside the margin at one end, has four small teeth at the tip (Pl. 3, fig. 21). These scales resemble those of $S$. spinosa very closely, but in $S$. spinosa the thickened margin does not continue all round the scale and there is reticulate thickening at the bristle end of the scale, this not being present in $S$. sphagnicola. The general appearance of the two organisms is so different that it should always be possible to separate them without depending on the scale structure.

Scale arrangement. Plate 4, fig. 23, is taken from a cell of Synura sphagnicola fixed in osmic acid vapour. A disordered ring of scales can be seen, and, in the middle, a patch of bare protoplasm. Plate 4, fig. 24, shows a similar group taken from the edge of a colony. We were unable to obtain an ordered array of scales, such as may be seen in other species of Synura (Pl. 4, figs. 25, 26). This was probably due to the fact that the fixative, whether a vapour or a liquid, penetrated the mucilage slowly, and the scales became detached before the organism had been killed. It is also possible that the scales never form a cohesive armour, as in other species, and are more easily and rapidly detached from the cell membrane.

Occurrence. Synura sphagnicola has been found frequently in acid ponds in the vicinity of Reading. It occurs in shallow pools associated with Sphagnum and in deeper ponds without Sphagnum and has been found both in 
woods and in the open. It usually occurs in summer, from May onwards, and persists even during warm weather when the ponds are drying up. It was found also in January and February of 1957 in a pond where it had not occurred during the previous summer. Possibly its occurrence was connected with the unusually mild winter.

Discussion. Synura sphagnicola differs from all other species of Synura both in the morphology of the cells and in the way in which they are united into colonies. The presence or absence of mucilage seems to be variable. We have always found it to be present in our material, and we have examined material in several years, in many different months, and from many localities. Fott \& Ludvik state that mucilage is nearly always present, Korshikov does not find it, and Jane informs us that he has demonstrated its absence on several occasions. $S$. sphagnicola, however, is not the only species of Synura which may possess mucilage. We have, at times, demonstrated mucilage around colonies of $S$. petersenii, though usually none is visible in this species. Fott \& Ludvik (1957) gives it as their opinion that $S$. sphagnicola and Syncrypta volvox Ehrenbg. are identical, that $S$. volvox is inadequately described and therefore the name Synura sphagnicola should remain and include the two synonyms. We are in entire agreement with this argument. Another incompletely described organism may be synonymous with $S$. sphagnicola, namely Volvochrysis xantha Schiffer (Huber-Pestalozzi, 1941), figures of which look very like S. sphagnicola. However, the description is different, but this may be discounted as it hardly agrees with its own figures.

\section{Synura echinulata Korshikov}

This organism is illustrated in Fig. 15 and in Pl. 4, figs. 25 and 26. Two replicas of the intact scale armour of Synura echinulata Korsh. are shown in Pl. 4, figs. 25 and 26. No replicas have yet been published, so far as we know, of the intact armour of any species of Synura. These replicas supplement the information given by Petersen \& Hansen (1956) with their beautiful direct electron micrographs of Synura species. It is also interesting to compare them with the disordered array of scales which we obtained for Synura sphagnicola by the same technique.

The authors would like to thank Professor F. Jane, Holloway College, for helpful suggestions, Professor J. M. R. Cormack, University of Reading, for the Latin translation of the diagnosis of Mallomonas ouradion, Miss P. E. Rush of the A.E.I. Research Laboratory for her help in the preparation of electron microscope specimens, Professor T. M. Harris, F.R.S., University of Reading, for help throughout the work, and Mr M. Twyman, Fine Arts Department, University of Reading, for the diagrams, Figs. 14-17. One of the authors (D.E.B.) would also like to thank Dr T. E. Allibone, F.R.S., Director of the Research Laboratory, Associated Electrical Industries Ltd., for permission to publish this paper. 


\section{REFERENCES}

Bradley, D. E. (1954a). An evaporated carbon replica technique for use with the electron microscope and its application to the study of photographic grains. Brit. J. appl. Phys. 5, 96.

Bradley, D. E. (1954b). Evaporated carbon films for use in electron microscopy. Brit. J. appl. Phys. 5, 65.

ConraD, W. (1941). Notes protistologiques XVIII. Sur Chrysosphaerella longispina Lautb. Bull. Mus. Hist. nat. Belge. 17, 7.

FotT, B. \& Ludvik, J. (1956). Elektronenoptische Untersuchung der Kieselstructuren bei Chrysosphaerella. Preslia, 28, 276.

FotT, B. \& Ludvik, J. (1957). Die Submikroskopische Struktur der Kieselschuppen bei Synura und ihre Bedeutung für die Taxonomie der Gattung. Preslia, 29, 5.

Harris, K. (1953). A contribution to our knowledge of Mallomonas. J. Linn. Soc. (Bot.), 60, 88.

Harris, K. \& Bradley, D. E. (1957). The examination of the scales and bristles of Mallomonas in the electron microscope using carbon replicas. J.R. micr. Soc. 76, 37.

Huber-Pestalozzi, G. (1941). Das Phytoplankton des Süsswassers. Die Binnengewässer. 16, 2 Tiel, 1 Hälfte. Stuttgart: E. Schwarzerbart'sche Verlagsbuchhandlung (E. Nasche).

Korshikov, A. A. (1929). Studies on the chrysomonads I. Arch. Protistenk. 67, 125.

Korshikov, A. A. (1941-42). On some new or little known flagellates. Arch Protistenk. 95, 22.

Lauterborn, R. (1896). Diagnosen neuer Protozoen des Oberrheins. Zool. Anz. 19, 14.

Lauterborn, R. (1899). Protozoen Studien. IV. Tiel. Flagellaten des Oberrheins. Z. wiss. Zool. 65, 369.

Manton, I. (1955). Observations with the electron microscope on Synura caroliniana Whitford. Proc. Leeds. phil. Soc. Scient. Sect. 6, part 5.

Petersen, B. (1918). Om Synura uvella Stein og Nogle andre Chrysomonadiner. Vidensk. Medd. dansk naturh. Foren. Kbh. 69, 345.

Petersen, B. \& Benth Hansen, J. (1956). On the scales of some Synura species. Biol. Medd., Kbh. 23, 1.

Skuja, H. (1948). Taxonomie des Phytoplanktons einiger Seen in Uppland, Sweden. Symb. bot. upsaliens. 9, 3.

Sмгтн, G. M. (1933). The Freshwater Algae of the United States, p. 173. New York: McGraw Hill.

\section{EXPLANATION OF PLATES}

\section{Plate 1}

Fig. 1. Mallomonas ouradion, direct electron micrograph of a scale; $\times 18,000$.

Fig. 2. M. ouradion, direct electron micrograph of a bristle; $\times 13,000$.

Fig. 3. M. ouradion, shadowed carbon replica of a scale with five bristles, one of which has the tip instead of the base towards the scale; $\times 3200$.

Fig. 4. M. ouradion, direct electron micrograph of a bristle tip; $\times 21,000$.

Fig. 5. M. ouradion, direct electron micrograph of a bristle base; $\times 21,000$.

Fig. 6. $M$. ouradion, shadowed carbon replica of underside of scales showing how bristles are attached; $\times \mathbf{8 0 0 0}$.

Fig. 7. M. ouradion, carbon replica of outer surface of a scale and also a bristle; $\times 6500$.

\section{Plate 2}

Fig. 8. Mallomonas ouradion, carbon replica showing one immature and several normal scales; $\times 10,000$.

Fig. 9. Chrysosphaerella brevispina, direct electron micrograph of bristle base $; \times 15,000$. 
Journal of General Microbiology, Vol. 18, No. 1
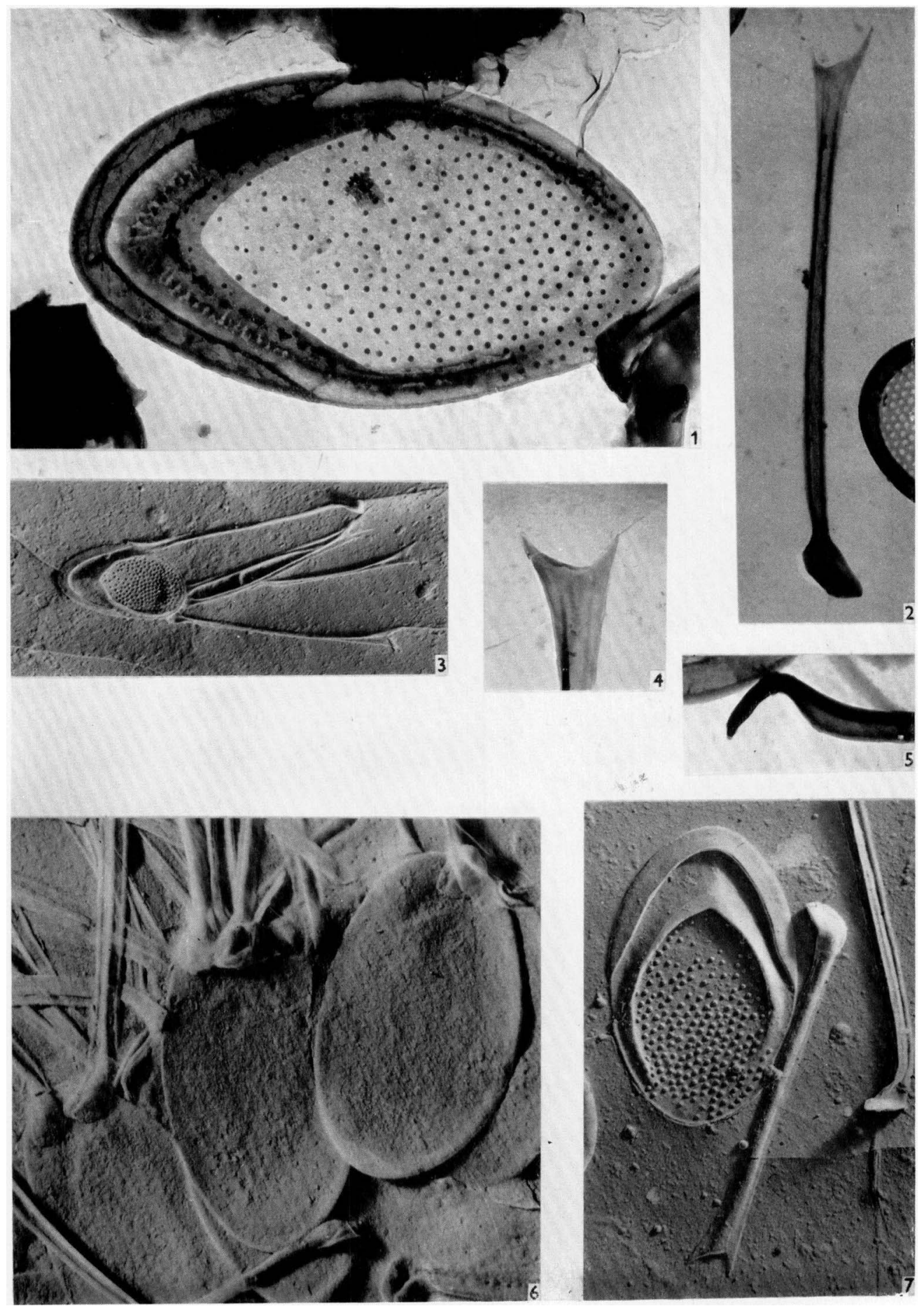

K. Itarnis \& D. F. Braduey-Unuscat chrsophyceaf stimied in electron microscope. Plate 1 
Journal of General Microbiology, Vol. 18, No. 1
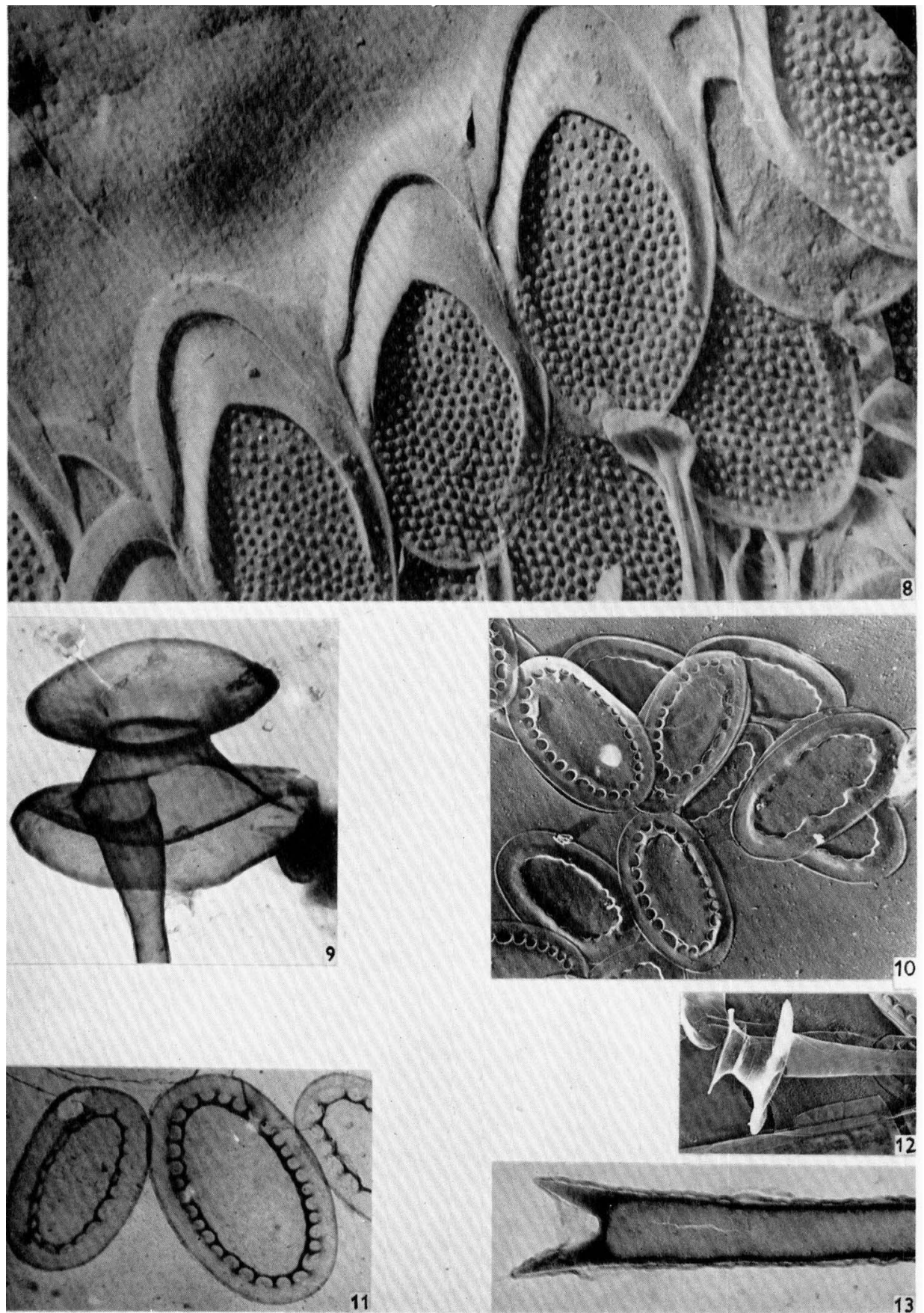

12

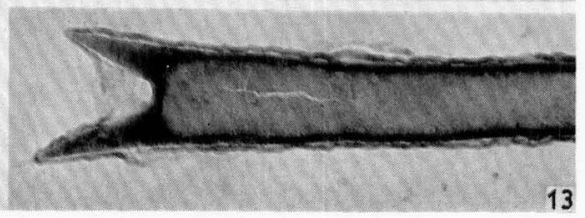

K. Harris \& D. E. Bradley--Unusual chrysopiryceate studied in fitectron microscope. Plate 2 
Journal of General Microbiology, Vol. 18, No. 1
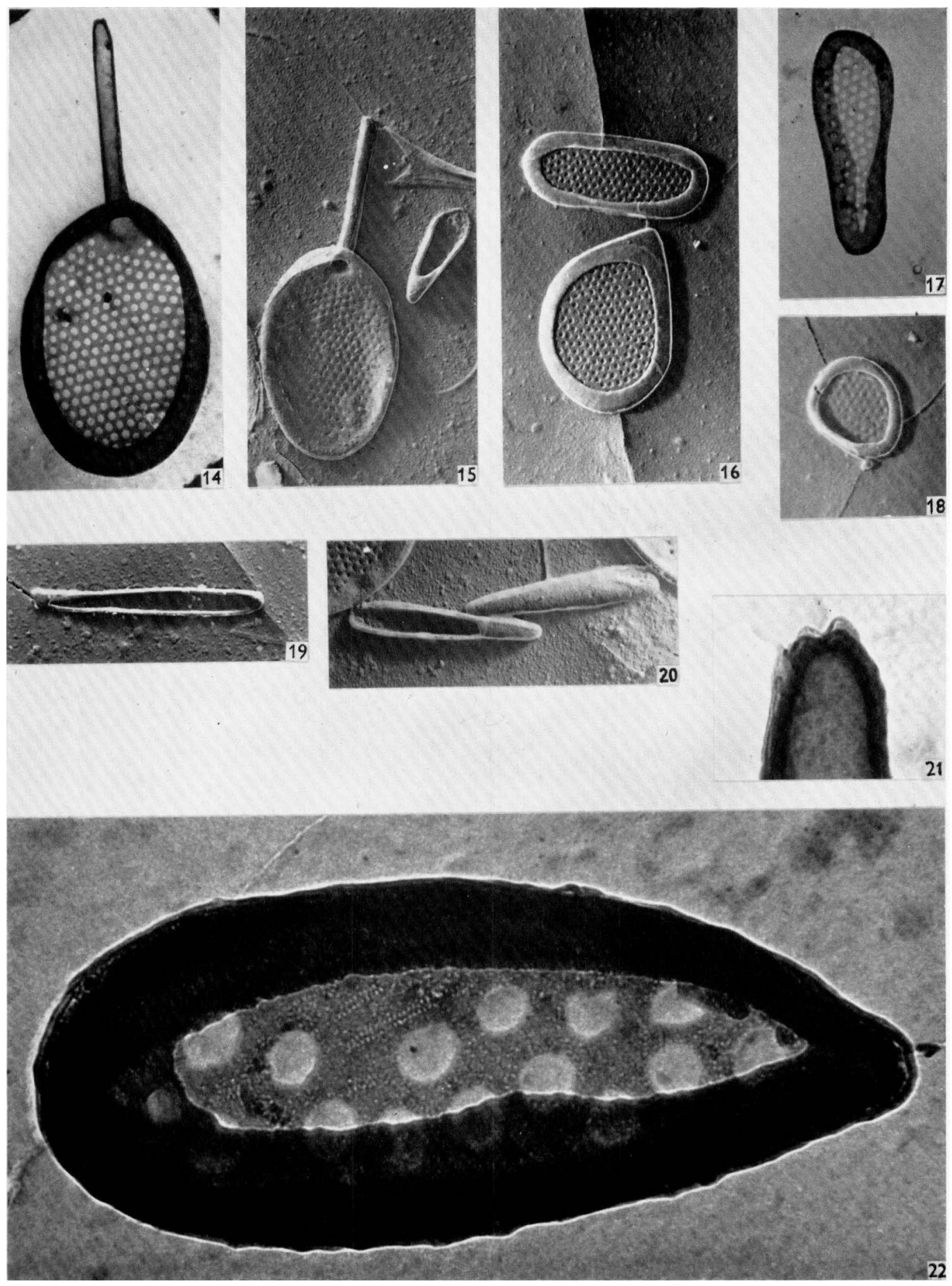

K. Harris \& D. E. Bradify-Unusual citrysopityctafe stumied in fitectron microscope. Piate 3 
Journal of General Microbiology, Vol. 18, No. 1
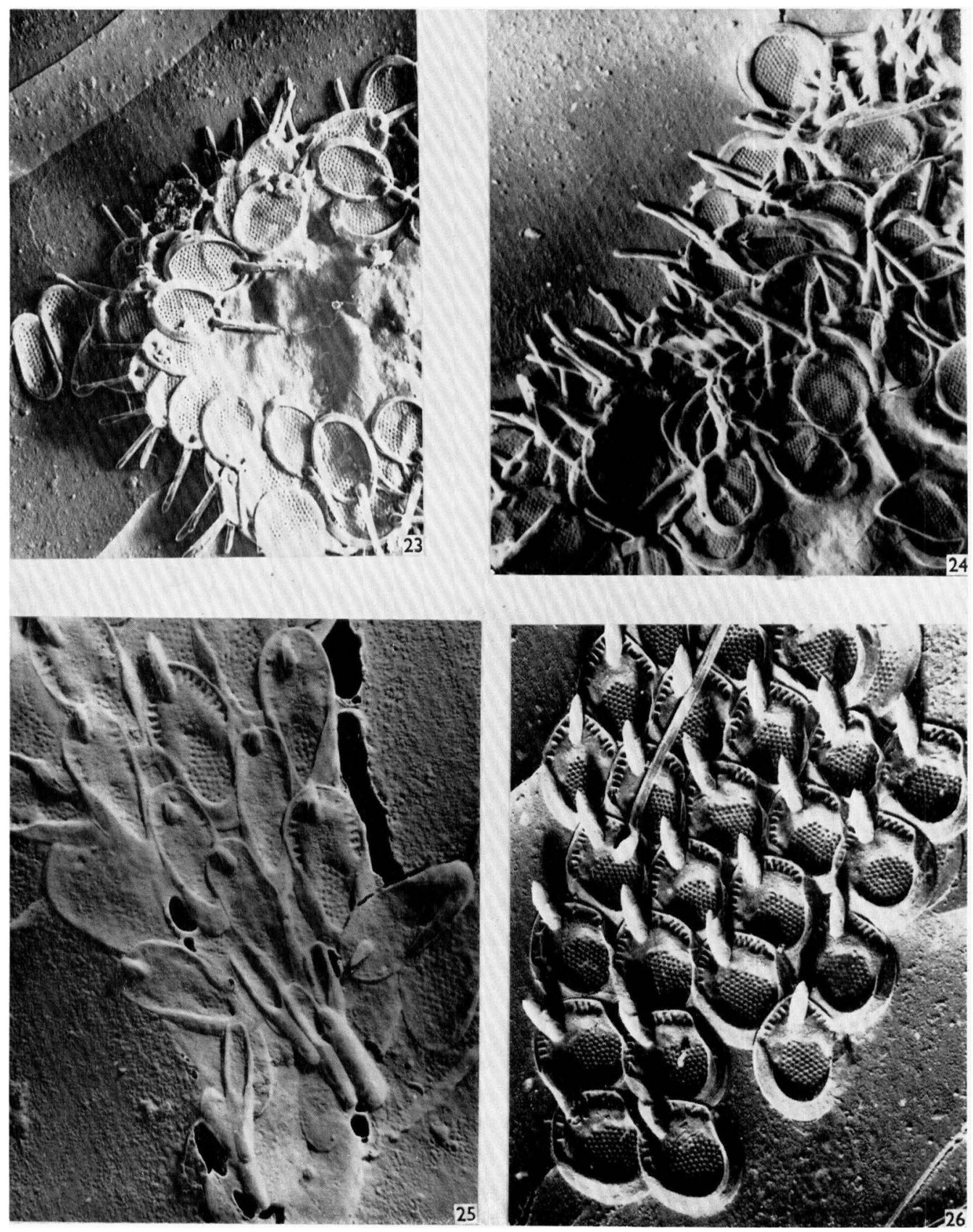

K. Harris \& D. F. Bradify-Unusual cirysopiychaf studied in Electron microscople. Plate 4 
Fig. 10. C. brevispina, shadowed carbon replica of scales showing inner and outer surfaces; $\times 6000$.

Fig. 11. C. brevispina, direct electron micrograph of scales; $\times 10,000$.

Fig. 12. C. brevispina, shadowed carbon replica of goblet-shaped bristle base; $\times 5500$.

Fig. 13. C. brevispina, fork-shaped bristle tip, direct electron micrograph; $\times 40,000$.

\section{Plate 3}

Fig. 14. Symura sphagnicola, direct electron micrograph of a scale with a spine; $\times 10,000$.

Fig. 15. S. sphagnicola, shadowed carbon replica of inner surface of scale with spine, and also spoon-shaped scale; $\times 7000$.

Fig. 16. S. sphagnicola, shadowed carbon replica of outer surfaces of scales without spines; $\times 8500$.

Fig. 17. S. sphagnicola, direct electron micrograph of scale approaching spathulate shape; $\times 15,000$.

Fig. 18. S. sphagnicola, shadowed carbon replica of a small circular scale; $\times 8000$.

Figs. 19 and 20. S. sphagnicola, shadowed carbon replica of spathulate scales-right-hand scale in fig. 20 is inverted; $\times 9000$.

Fig. 21. S. sphagnicola, direct electron micrograph of the tip of a spine similar to that in fig. $14 ; \times 105,000$.

Fig. 22. S. sphagnicola, direct electron micrograph of a small scale showing slits; $\times 120,000$.

Plate 4

Fig. 23. Synura sphagnicola, shadowed carbon replica of an array of scales surrounding protoplasm; $\times \mathbf{4 0 0 0}$.

Fig. 24. S. sphagnicola, shadowed carbon replica of another array; $\times 4000$.

Fig. 25. Synura echinulata, shadowed carbon replica of the stalk; $\times 7000$.

Fig. 26. S. echinulata, shadowed carbon replica of an array of scales (outer surface); $\times 5000$.

(Received 11 July 1957) 